\title{
Property types diversification strategy of Malaysian real estate investment trust (M-REITs)
}

\author{
Tiong Chai Ping ${ }^{1}$, Rohaya Abdul Jalil2a \\ ${ }^{1}$ Department of Real Estate, Faculty of Geoinformation and Real Estate, \\ ${ }^{2}$ Centre for Real Estate Studies, Institute for Smart Infrastructure and Innovative Construction, Universiti Teknologi Malaysia, 81310 UTM Skudai \\ Johor, Malalysia
}

\begin{abstract}
The aim of this paper is to review the property types diversification strategy of Malaysian REITs. Previous study has found that Malaysian REITs received poor response form investors both local and international. Furthermore, the underperformance of Malaysian REITs was linked to the characteristics of REITs' property types and REITs' portfolio influenced its financial performance. The lack of local study on both of these determinants of influence on performance of Malaysian REITs is a research gap, which needs to be explored that can provide more insight of it. This study showed that the property types such as office space, commercial lot, industrial, hotel and specialized property type are the important determinants, which can influence the performance of REITs. The study comprised of REITs data from 2010 until 2014, and through Multiple Regression Analysis (MRA) reveals there is little influence of property types diversification strategy toward Malaysian REITs' performance. Nevertheless, by employ correlation analysis between each of the five property types with expected return and dividend yield, this study shows Malaysian REITs' performance of dividend yield(DY) has a positive correlation value with commercial lot property type and Malaysian REITs' performance of expected return(ER) have a highest positive correlation value with industrial property types. Also, this study suggests that property type diversification play a significant role in Malaysia REITs. Other determinants such as location of property, market capitalization and REITs' quality of advisory style that might influence the diversification strategy and financial performance of Malaysian REITs.
\end{abstract}

\section{Introduction}

Real Estate Investment Trust (REIT) is one type of indirect real estate investment. REIT is owned by listed companies that actively manage the portfolio of high quality income of real estate such as commercial office, hotel, retail mall, etc. In general, REIT must invest at least 50 percent of its total assets in real estate and the principal assets of the companies whose governed the REIT must be real estate (REITs Guidelines, 2012). Although REIT is being listed in the stock market but the rental income secures the income stream. REIT is required to distribute its 90 percent of taxable income to shareholders annually in the form of divided. So, these characteristics of REIT make it as a hybrid investment offering liquidity as stock and the income stream, secured by a long lease in quality commercial real estate (Newell, 2012). Furthermore, REITs are investment vehicles, which are able to provide wider diversification opportunities, greater liquidity of funds, ease of operations, and the ability to diversify at any level of investments (Chan et al, 2003 and Zietz et al, 2003).

In 1989, Malaysia introduced Property Trust Fund (PTF) market but received limited support from the investors due to structural factor (Newell and Osmadi, 2010). This led to the establishment of first Malaysian REITs in August 2005 after Securities Commission of Malaysia issued new guidelines for M-REITs. Besides, the successful introduction of REITs in other Asian countries such as Japan, Hong Kong and Singapore also encouraged Malaysia to developed REITs. However, Malaysian REITs received inadequate response and from institutional investors and the participation rates of investors in M-REITs are much lower than other counties (Jalil and Ali, 2015; Newell and Osmandi, 2009).

Jalil and Ali (2015) found that the type of underlying property of REITs is one of the determinants, which influences the performance of M-REITs. For example, REIT which focuses on only single type of property in their property portfolio will enjoy large liquidity than REITs with several types of property in its portfolio (Danielsen and Harrison, 2007). Besides, Gyourko and Neilling (1996) state that the property type of REITs invested in influence the systematic risk of REITs. Then, Hartzell et.al (1986) noted that there is low correlation between different types of properties while they were analysing the returns on an institutional real estate portfolio. They suggest that diversification across property types might have benefits. In addition, REITs stock is hybrid in nature. As the primary return of REITs is generated from the rental of underlying property and the rates of rental are associated with the quality of property types , thus, the quality of underlying property type are important in the return for REITs stock. (Chan et.al. 2003, Hui et.al. 2007; Newell, 2012).

Besides, by taking consideration of property type's concentration, either pure-played or diversified strategy in REITs are provide benefits in return enhancement and risk reduction in REITs portfolio (Danielsen and Harrison, 2007; Benefield, 2006; Young, 2000; Capozza

\footnotetext{
a Correspondence Author: rohaya@utm.my
} 
and Lee, 1995). Basically, property type is a common factor which used to examine the performance of REITs for many previous studies. Extensive research to examine the performance of REITs by employed property type has been conducted in U.S and U.K. However, little is studied in Malaysia about the performance of REITs in terms of analysis of REITs. This is relevant, specifically to equity investors, whether local or international who are interested to enter the Malaysia REITs especially in terms of property type.

Thus, this study aims to investigate whether the property type important in M-REITs performance and analyse the performance of M-REITs based on the property type by employ correlation analysis and Multiple Regression Analysis using market value of the underlying assets of REITs from year 2010 to 2014. The first objective of this study is to investigate the influence of property types strategy upon M-REITs' financial performance. While, the second objective of this study is to examine the performance differences between properties' type diversification of pure-played and diversified.

\section{Literature review}

\subsection{Property type's performance}

Property trust funds are the predecessor of REIT in Malaysia. However, this property trust fund was not popular among the institutional investors due to the regulation framework which provide no tax transparency (Newell, Ooi and Sing, 2006).The development of REITs in Malaysia started when the Securities Commission (SC) issued new guidelines in the year 2005 to provide a legal framework for better monitoring of the REITs stock. The key features of the revision of guidelines by $\mathrm{SC}$ in the year 2005 is included grating tax transparency status and liberalizing REIT's borrowing limits to 35 percent of asset value. With the revision of new guidelines, a property trust fund was renamed to Real Estate Investment Trust (REIT) which is the global adopted term. With all these changes, the first REIT in Malaysia which is Axis REIT was listed in August, 2005.

According to guidelines on Malaysia Real Estate Investment Trust which issued by Securities Commission Malaysia, Malaysia REIT can only invest in real estate, single -purpose companies, real estaterelated assets, non-real estate-related assets , cash, deposits, and money market instrument. Apart from this, the total asset value of at least 50 percent must be invested in property or single-purpose companies at all time.

Besides, investment in non-property- related assets and cash cannot excess 25 percent of the total assets value of Malaysia. In addition, Malaysia REITs are prohibited from property development, but they can acquire property under construction with the prior that the total value acquired does not exceed 10 percent of the fund's total asset value. Moreover, for gearing requirement, the borrowing limit for Malaysia REITs is maximum up to 50 percent of the total asset value of the fund and are require to consider the risk of borrowings and the impact of the borrowings based on the requirement of the guideline of Securities Commission. Malaysia REITs excluded from tax when they distribute at least 90 percent of the total income to their shareholders. Currently, there are total seventeen REITs companies listed in the Bursa Malaysia. Table 1 indicates the summary of M-REITs and their respective property types.

Table 1: Summary of M-REITs property types Sources: Bursa Malaysia

\begin{tabular}{|c|c|c|}
\hline No. & REIT & Property Portfolio \\
\hline 1. & $\begin{array}{l}\text { Amanah Harta } \\
\text { Tanah PNB }\end{array}$ & Retail, Office \\
\hline 2. & $\begin{array}{l}\text { Al-Aqar } \\
\text { Healthcare REIT }\end{array}$ & $\begin{array}{ll}\text { Hospital, } & \text { Nursing } \\
\text { College, Hotel }\end{array}$ \\
\hline 3. & AmFirst REIT & Office, Retail, Hotel \\
\hline 4. & $\begin{array}{l}\text { Amanah Raya } \\
\text { REIT }\end{array}$ & $\begin{array}{l}\text { Industrial, Office, Hotel, } \\
\text { Institution, Retail }\end{array}$ \\
\hline 5. & Atrium REIT & Industrial, Office \\
\hline 6. & Axis REIT & Office, Industrial \\
\hline 7. & Al-Salam REIT & Retail \\
\hline 8. & $\begin{array}{l}\text { CapitalMalls } \\
\text { Malaysia Trust }\end{array}$ & Retail \\
\hline 9. & Hektar REIT & Retail \\
\hline 10. & IGB REIT & Retail \\
\hline 11. & KLCC REIT & Retail, Office \\
\hline 12. & Pavilion REIT & Retail, Office \\
\hline 13. & $\begin{array}{ll}\text { Quill } & \text { Capital } \\
\text { Trust } & \end{array}$ & $\begin{array}{l}\text { Office, Industrial, } \\
\text { Commercial Carpark }\end{array}$ \\
\hline 14. & Starhill REIT & $\begin{array}{l}\text { Commercial, Convertible } \\
\text { Preference Units of REIT }\end{array}$ \\
\hline 15. & Sunway REIT & Retail, Hotel, Office \\
\hline 16. & Tower REIT & Retail \\
\hline 17. & UOA REIT & Retail \\
\hline
\end{tabular}

The property types of REITs portfolio are the main determinants which affect the REITs performance and the quality of the underlying assets of REITs is one of the attractive investment features for investors to invest in REITs (Newell, 2012).Typically, the portfolios of REITs are classified as pure-play if the REITs portfolio held $75 \%$ or more of it portfolio in one type of property. 
Whereas, if a REITs has held less than $75 \%$ of its portfolio invested in any one property type, then it is classified as diversified (Ambrose and Linneman, 2001; Benefield et. al., 2008). Generally, REITs are invested in high value and high profile real estate such as hotel, shopping mall or office tower in Malaysia (Wong, 2015). Besides, some REITs market are invested not only in commercial building but also residential and industrial (Pham, 2012).

REITs' performance are different based on the underlying property type owned, and it is able to provide diversification opportunity for investors by diversified the property types of REITs property portfolio (Newell and Tan, 2003). The performance of REITs has generally been related to the rental income of their underlying property asset as the main revenue of REITs is from their underlying property asset (Olarele et.al. 2015).Thus, the underlying property type will influence the market share price of REITs as different type of property are subjected to charge for different rental rate based on local property market. In addition, different underlying property type of REITs poses different property nature and thus will bring a different effect upon the net asset value and also performance of REIT stock (Ong et.al. 2011). Therefore, based on the literature above, it is not surprised that property types are one of the determinant which will influence the REITs' performance.

For M-REITs, property type is one of the determinants to evaluate the performance of Malaysia REITs and many REITs are individually focused in property type. (Jalil and Ali, 2015). In general, the REIT with largest size focus more on retail property while smallest size REITs are more focus on office and industrial property. The study on the office buildings, showed that office rental value can be explained by demand side variable in particular real GDP and employment rate in service sectors (Bruno et.al., 1992). Furthermore, the study of Kim et.al (2002) and Kim and Jang (2012) on hotel REIT revealed that hotel REIT has higher market risk than other REIT property sectors and underperformed office, industrial and diversified REITs sector in terms of portfolio or individual stock. In their study, they also pointed out that room occupancy rate, oversupply of lodging properties in property market and hotel financing policy is the factors affecting the performance of the hotel REITs. In addition, study by Tang and Jang (2008) show that hotel REIT performance is positively influenced by tax-exempt status and mandatory income distribution requirements but negatively influenced by operating expenses.

By employed regression analysis on annualized per area net rental income of retail mall, Hui et.al. (2007) find that the age of the retail mall have a negative impact on the rental rate while the size (Gross Floor Area) and the total number of shop inside the shopping mall have a positive impact on the rate of rental. Whereas, their result showed that occupancy rate has no significant impact on rate of rental for retail mall.

Moreover, in terms of physical factors, there are eleven variables, which are building size, office space, dock doors, ceiling height, age, distance to the Dallas/Fort
Worth Airport, county of sale, industrial cap rate, prime rate, tenant type, and date of sale can be explain the sales price of industrial property (Fehribach et.al. ,1993). Later, the study of Benjamin et.al. (2003) also stated that physical characteristics of property, local market factors and location affect the value of industrial property. Also, the study of Ambrose (1990) stated that clientele effect would bring influenced to the value of industrial buildings. Besides, the study of Capozza and Lee (1995) stated that the stock market will place higher values in retail REITs and lower value on warehouse REITs based on the local property market. Apart from this, nontraditional property type in REITs such as healthcare centre or facility, self-storage and entertainment property provided wider diversification benefit than traditional property type such as retail and office space (Newell and Pang, 2006). All of the previous study stated above provided an evidence that different property types are influenced by different factors, and thus it is believed that they will possess different financial performance on MREITs. Therefore, this study will examine the each of the five property types toward M-REITs' performance.

There have different argument in terms of property portfolio concentration either pure-play or diversified property portfolio. Pure play property portfolios of REITs are more benefited than diversified property portfolio as diversified REITs seem to be riskier due to its low collateral value of assets (Morri et.al, 2008). In contrast, Ziobrowski et.al. (2009) stated that pure-play property portfolio have higher market risk than diversified risk as they only focus on one type of property investment and thus the risk cannot be diversified away since different property type influenced by different internal or external factors. Thus, this study will examine the performance differences between property portfolios of pure-play and diversified of M-REITs.

\subsection{REITs' performance measurement}

In stock markets, investors are basically looked at the total return and the volatility of stock in making investment decisions. Nevertheless, because of the tax regulations of the REITs which require REITs to payout 90 percent of taxable income to shareholders, thus, dividend payout of REITs is a significant performance measurement for REITs investors (Chan et.al.,2003).There have empirical studies on REITs performance analysis done in US REITs. However, in Malaysia, there have been limited studies on performance analysis on M-REITs especially based on property types.

For M-REITs or predecessor of M-REITs which is listed property trust, Newell, Ting and Acheampong (2002) have used annual return of four listed property trust in Malaysia for the period from 1991 to 2000 to examine their performance. The results show that the annual return of Amanah Harta Tanah PNB is higher than market return. Later, Hamzah et.al (2010) had using Sharpe ratio, Treynor Index and Jenson Ratio to examine the performance of M-REITs for pre-GFC, during GFC and post-GFC period by employed monthly return from 
period 1995 to 2005. In the study of Pham (2012) who used average return as the performance indicator for the Asian emerging and developed REITs markets, found that the M-REITs have the highest average return $(0.053 \%)$ among the seven Asian REITs market in the study.

Furthermore, Benefield, Anderson and Zumpano (2009) were obtained a daily return for the sample REITs in their study to examine the performance difference between diversified property type REITs and specialized REITs. Their result show that diversified property type REITs are performing better than specialized property type REITs when the overall market are performed well. The study of Myer and Webb (2000) found that the return data of the property type allocation are useful in explaining the performance of REITs. The study of Breidenbach et.al. (2006) was used quarterly return series to calculate the beta of different property types in different location.

As mentioned above, dividend yield is a significant performance indicator for REITs because of REITs tax regulations. By using Multiple Regression Analysis (MRA), the study of Olanrele et.al. (2014) proved that some financial factors of M-REITs such as Net Asset Value (NAV), size, gearing/leverage and Fund from Operations (FFO) have influenced on the M-REITs performance. They adopted quantitative research method and selected three M-REITs which are Amfirst REITs, Starthill REITs and AmanahRaya REITs as sample for the period from 2008 to 2012 . The study resulted that all the factors significantly contribute up to 91.7 percent of REIT return $\left(\mathrm{R}^{2}=0.917\right)$ through analysis of MRA.

Casey et.al. (2006) employed linear regression analysis and used dividend yield of REITs sample as independent variable to test it impact on REITs capital structure. The results show that dividend yield is significant to the capital structure of REITs, this may due to REITs pay out significantly more dividend as they have more cash flows arising from depreciation shelter. In addition, there have also several studies such as Wang et.al. (1993), Zietz et.al. (2003) and Lee et.al. (2010) who focus on the influence of dividend yield on REITs and point out that dividend yield has influence on REITs performance. The study of Wang et.al. (1993) found that REITs manager paid more dividend when REITs perform poorly.

Also, the study of Lee et.al (2010) resulted that the excess dividend payout is able to convey information to capital market and thus can gaining access to fund acquisition. This result make consensus with the study of Wang et.al. (1993) who find that dividend announcement did convey information to the market and the dividend policies can be used as a tool to convey private information about REITs future cash flow. This perhaps will influence the stock price of REITs as some of the investors will look at the dividend payout of REIT companies in making investment decision. Thus, this study will use expected return and dividend yield as performance indicator for M-REITs to examine the influence of different underlying property types on MREITs.

\section{Data}

There are a total of seventeen Malaysia listed REITs listed in Bursa Malaysia. For this study, fourteen Malaysia listed REITs were included, which are Amanah Harta Tanah PNB REIT, Al-Aqar Healthcare REIT, AmFirst REIT, Amanah Raya REIT, Atrium REIT, Axis REIT, CapitalMalls Malaysia Trust, Hektar REIT, IGB REIT, Pavilion REIT, Quill Capital Trust, Sunway REIT, Tower REIT and UOA REIT. This study will exclude KLCC and Al-Salam REIT due to their shortest listed period and Starhill REIT due to most of their underlying property assets is located outside Malaysia boarders. For M-REITs property portfolio, the property invested in the portfolio are office space, commercial lot, industrial property, education building and healthcare building. For this study, education building and healthcare building will be categorized as specialized property. The data were collected from REIT company annual report and DataStream. Monthly net property rental income of underlying property of REITs, market value of property and annual dividend payout of REITs were collected from REIT company annual report from 2010 to 2014, whereas, quarterly REITs stock closing price from period 2010 to 2014 were collected from DataStream.

\section{Methodology and variables}

This study will follow the empirical study of Jalil and Ali (2010) and Anderson and Shain (2001) by employed Multiple Regression Analysis (MRA) to test the relationship between expected return and divided yield of M-REITs with their property types. MRA is a method for explaining the relationship between dependent variable $(\mathrm{X})$ and independent variable $(\mathrm{Y})$. In MRA model, the correlation coefficient between dependent and independent variable is a quantitative index of association between these two variables. A multivariate counterpart of the coefficient of determination is the coefficient of multiple determination, $R^{2}$ value. Hence, the value of $R^{2}$ explains the degree of significant influence of independent variables toward dependent variable. The general forms of the models' specification are as follows:

$$
\begin{aligned}
& Y_{1}=a+b_{1} x_{1}+b_{2} x_{2}+b_{3} x_{3}+b_{4} x_{4}+b_{5} x_{5}+e \\
& Y_{2}=a+b_{1} x_{1}+b_{2} x_{2}+b_{3} x_{3}+b_{4} x_{4}+b_{5} x_{5}+e
\end{aligned}
$$

Where:

$\mathrm{Y}_{1}=$ Expected Return

$\mathrm{Y}_{2}=$ Dividend Yield

$\mathrm{a}=$ Constant

$\mathrm{b}=$ Coefficient of the Variables

$\mathrm{X}_{1}=$ Office Space

$\mathrm{X}_{2}=$ Commercial Lot

$\mathrm{X}_{3}=$ Industrial

$\mathrm{X}_{4}=$ Hotel

$\mathrm{X}_{5}=$ Specialized Property 
In addition, this study will use correlation analysis to measure the relationship between dependent variable and independent variables. The resulting value (correlation coefficient) will shows the changes in independent value will result in changes in dependent value. Also, correlating expected return and dividend yield with property types of REITs can provide information about the diversification by property types in REITs investment. The correlation coefficient poses positive or negative sign in the resulting result. The positive sign means that the change in the independent variable will result in the identical changes in dependent variables, whereas, the negative sign mean the changes in independent variable will result in the identical changes in dependent variables also but the changes will be in opposite direction.

\subsection{The Dependent Variables}

In this study the dependent variables is the performance measurement of REITs which are expected return $\left(\mathrm{Y}_{1}\right)$ and dividend yield $\left(\mathrm{Y}_{2}\right)$ to examine the performance of M-REITs based on property. The expected returns are the common performance indicator use by the investor when making investment decision, thus this study will use quarterly expected return of M-REITs to examine the performance of a short term investment goal. Generally, the expected return is a predicted or estimated return that may or may not occur (Omisore, Yusuf and Christopher, 2011). It is the amount of return of the investors looking forward to receive over the period of investment. This expectation of the investors usually builds on the historical performance from the particular investment. The calculation for the expected return is shown as follows:

$$
\mathrm{E}(\mathrm{R})=\left(\frac{P_{1}-P_{0}}{P_{0}}\right) * 100
$$

Where,

$\mathrm{E}(\mathrm{R})=$ Quarterly Expected Return

$\mathrm{P}_{1}=$ Daily price of REIT stock at the end of the quarter

$\mathrm{P}_{0}=$ Daily price of REIT stock at the beginning of the quarter

Whereas, because of the unique tax regulation of REITs which pay out $90 \%$ of their dividend per annual, thus, dividend yield is also another performance indicator for REITs to examine the long term investment goals. The calculation for dividend yield is shown as below:

$$
\mathrm{DY}=\frac{\text { Annual Dividend Distribution }}{\text { Stock Price }}
$$

Where,

$\mathrm{DY}=$ Dividend Yield

\subsection{The independent variables}

The literature above revealed that property types are one of the determinants which as influenced toward REITs performance. Thus, it is a need to study the properties' portfolio of M-REITs. Based on the thorough study of fourteen listed M-REITs annual company report, MREITs companies consists of office space, commercial lot, industrial properties, hotel healthcare property and educational buildings. So, the independent variables for this study are office space $\left(\mathrm{X}_{1}\right)$, commercial lot $\left(\mathrm{X}_{2}\right)$, industrial property $\left(\mathrm{X}_{3}\right)$, hotel $\left(\mathrm{X}_{4}\right)$ and specialized property $\left(\mathrm{X}_{5}\right)$, which comprised of healthcare and educational property. The annually market value of each underlying property of fourteen listed REITs companies included in this study will aggregate in those five property types.

\subsection{Research Design}

Overall, this study aims to examine the relationship and influences of M-REITs property types toward M-REITs performance. The overall idea of this study is show in figure 3.1 below:

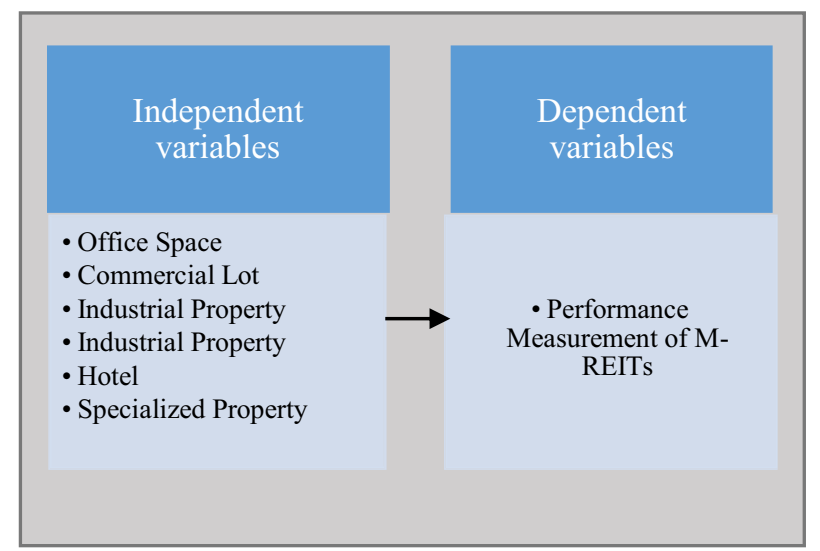

Figure 1: Relationship of Property Types with MREITs Performance

The annually market value of each underlying property of fourteen listed companies was collected from the company's annual report and aggregated in five property types mentioned above. Expected return and dividend yield are calculated by using the stock price collected from DataStream and dividend distribution of each REITs company from annual report. Correlation analyses were employed to test the relationship between each property type with expected return and dividend yield. Also, MRA are employed to test the influenced of all the five property types towards expected return and dividend yield. The result of the analysis are show in the section below.

\section{Results and discussion}

The finding of first objective for this study is to investigate the influence of property types strategy upon M-REITs' financial performance are presented in Table 2 below. It presents the result of correlation analysis between five property type of M-REITs (office space, 
commercial lot, industrial property, hotel and specialized property).

Table 2: Result for Correlation Analysis

\begin{tabular}{|c|c|c|c|c|c|}
\hline $\begin{array}{l}\begin{array}{r}\text { Independent } \\
\text { variables }\end{array} \\
\text { Dependent } \\
\text { Variables }\end{array}$ & $\mathbf{X}_{1}$ & $\mathbf{X}_{2}$ & $\mathbf{X}_{3}$ & $\mathbf{X}_{4}$ & $\mathbf{X}_{5}$ \\
\hline $\mathrm{Y}_{1}(\mathrm{ER})$ & -0.113 & 0.0351 & 0.1860 & 0.1258 & 0.0144 \\
\hline $\mathrm{Y}_{2}(\mathrm{DY})$ & -0.114 & 0.084 & -0.039 & -0.039 & -0.051 \\
\hline
\end{tabular}

The correlation analysis show that the expected return of M-REITs have the highest positive correlation value with industrial property $(0.1860)$ follow by hotel (0.1258), commercial lot $(0.0351)$ and specialized property (0.0144). Whereas, expected return of M-REITs have negative correlation value with office space (0.113 ). Industrial property in M-REITs have a stable return because the tenants for the industrial properties are mainly the tenants with famous brand and good reputation and they are the only tenants for that particular industrial buildings such as BMW, Nestle and Emerson for Axis REIT and DHL Sdn Bhd for Atrium REITs. This finding result are make consensus with the study of Ambrose (1990) who suggest that clientele effect will bring influenced to the value of industrial buildings.

For dividend yield of M-REITs, only commercial lot have a positive correlation value with M-REITs dividend yield while another four property types all have negative correlation value with dividend yield as show in the table above. In M-REITs, the commercial mall are mainly located in large and densely populated cities such as Kuala Lumpur. The location of the commercial mall encouraged the high traffic of consumer and also the tenants, thus, this directly will increase the net property rental income of commercial buildings and consequently the REITs companies will pay out high dividend yield. This result are align with the study of Lehew (2000) who stated that the successful commercial mall properties are located in large and densely populated region. In addition, the study of Gyourko and Nelling (1996) stated that commercial mall have higher return compared to industrial property but also associated with high risk also. Nevertheless, the result show that property types have less influenced on expected return and dividend yield on M-REITs. Although some property types have a positive correlation with expected return and dividend yield, yet, on the simultaneous effect, by using MRA, the study found that all the five independent variables are shows lower $\mathrm{R}^{2}$ value towards expected return and dividend yield of M-REITs. Table 3 show the regression model summary of property types with expected return and Table 4 show the regression model summary of property types with dividend yield. Based on the result show in Table 3 and Table 4 , the $R^{2}$ value for regression analysis of property types with expected return and dividend yield are 8.3 percent and 2.3 percent respectively. Also mean that other factors which were not consider in this study contribute 91.7 percent and 97.7 percent to the influence on expected return and dividend yield on M-REITs.

Table 3: Regression model summary of property types with expected return

\begin{tabular}{|c|c|c|}
\hline $\boldsymbol{R}$ & $\boldsymbol{R}^{\mathbf{2}}$ & ${\text { Adjusted } \boldsymbol{R}^{\mathbf{2}}}$ \\
\hline 0.289 & 0.083 & 0.007 \\
\hline
\end{tabular}

Table 4: Regression model summary of property types with dividend yield

\begin{tabular}{|c|c|c|}
\hline $\boldsymbol{R}$ & $\boldsymbol{R}^{\mathbf{2}}$ & ${\text { Adjusted } \boldsymbol{R}^{\mathbf{2}}}$ \\
\hline 0.151 & 0.023 & -0.059 \\
\hline
\end{tabular}

From the data presented in Table 2, 3 and 4, it is clear that all the five property types have little influenced on expected return and dividend yield of M-REITs from period 2010 to 2014 . This lower $\mathrm{R}^{2}$ value may due to REITs financial performance are influenced by many others factors also. From the literature review on the performance of REITs, it is pointed out that REITs performance are influenced by financing policy, management style, location of property, net asset value and size of stock of REITs (Jalil and Ali, 2015; Ong, 2011; Ong.et.al,2012; Kim and Jang,2012 ; Anderson and Shain, 2001). Besides, the study of Olanrele et.al. (2014) proved that some financial factors of M-REITs such as Net Asset Value (NAV), size, gearing/leverage and Fund from Operations (FFO) have influenced on the M-REITs dividend yield. They study resulted $91.7 \%$ influenced of all these factors towards M-REITs return and dividend yield.

In addition, the preferences of tenant is also the factors which can influenced the performance of REITs, as highlighted by the study of Celka (2011) which had categorized the preferences of tenants on office property market. The study revealed that main preferences of tenant are location and accessibility of the property, facility provided by the office buildings such as number of parking space, building characteristics and building design.

Although lower $\mathrm{R}^{2}$ value are shown between five property types with M-REITs 'financial performance, yet this study would like to emphasis on the property types diversification effects. Thus, we further examine the M-REITs' average rental yield from year 2010 to 2014. The average office space rental yield of M-REITs are shown in the Table 5 below. Rental yield can be REITs' performance indicator, as when rental yield are performed well, REITs are able to distribute high dividend and will attract investors. Thus, higher distribution of dividend motivated higher unit price for REITs. 
Table 5: Average office property rental yield of M-REITs

\begin{tabular}{|l|c|c|c|c|c|}
\hline \multicolumn{1}{|r|}{ Year } & $\mathbf{2 0 1 0}$ & $\mathbf{2 0 1 1}$ & $\mathbf{2 0 1 2}$ & $\mathbf{2 0 1 3}$ & $\mathbf{2 0 1 4}$ \\
& & & & & \\
\hline Amanah Raya & & & & & \\
\hline Amfirst & 0.07 & 0.068 & 0.07 & 0.075 & 0.076 \\
\hline Axis & 0.052 & 0.054 & 0.047 & 0.059 & 0.055 \\
\hline Quill Capital & 0.065 & 0.072 & 0.069 & 0.071 & 0.067 \\
\hline Tower & 0.095 & 0.096 & 0.09 & 0.09 & 0.09 \\
\hline UOA & 0.083 & 0.09 & 0.09 & 0.087 & 0.067 \\
\hline Pavillion & 0.083 & 0.078 & 0.082 & 0.082 & 0.088 \\
\hline Sunway & - & - & 0.05 & 0.06 & 0.04 \\
\hline AHP & - & 0.053 & 0.076 & 0.063 & 0.063 \\
\hline
\end{tabular}

The rental yield associated with quality of property buildings (Hui et.al. 2007). Based on the average rental yield of office space, it is clearly show that the average rental yield of Quill Capital REIT, Tower REIT, UOA REIT, Sunway REIT, Axis REIT and AHP REIT performed good and stable from year 2010 to 2014 which is more than 6 percent. This is due to the location of REITs that located in the Centre Business District (CBD) which have a higher demand and occupancy rate. Meanwhile, Amfirst REIT and Pavillion REIT derived less than 6 percent of average rental yield for office space, this mainly caused by the lower occupancy rate of office space and thus reduce the net rental income.

The finding of second objective of this study which is to examine the performance differences between property type diversification of pure-played and diversified is shown as Table 6 below.

Table 6: Average property rental yield of pure-played REITs and diversified REITs of M-REITs

\begin{tabular}{|l|l|l|l|l|l|l|}
\hline REITs & \multirow{2}{*}{$\begin{array}{l}\text { Property } \\
\text { diversifica } \\
\text { tion } \\
\text { strategy }\end{array}$} & \multicolumn{5}{|l}{ Average Rental Yield (\%) } \\
\cline { 3 - 7 } & Pure-Play & $\mathbf{2 0 1 0}$ & $\mathbf{2 0 1 1}$ & $\mathbf{2 0 1 2}$ & $\mathbf{2 0 1 3}$ & $\mathbf{2 0 1 4}$ \\
\hline $\begin{array}{l}\text { Amanah } \\
\text { Harta Tanah } \\
\text { AHP) PNB }\end{array}$ & & & & & & 0.083 \\
\hline $\begin{array}{l}\text { Al-Aqar } \\
\text { Healthcare } \\
\text { REIT }\end{array}$ & Pure-Play & 0.075 & 0.07 & 0.067 & 0.07 & 0.07 \\
\hline $\begin{array}{l}\text { AmFirst } \\
\text { REIT }\end{array}$ & Pure-Play & 0.056 & 0.064 & 0.049 & 0.058 & 0.054 \\
\hline $\begin{array}{l}\text { Amanah } \\
\text { Raya REIT }\end{array}$ & Diversified & 0.07 & 0.069 & 0.071 & 0.074 & 0.065 \\
\hline $\begin{array}{l}\text { Atrium } \\
\text { REIT }\end{array}$ & Pure-Play & 0.085 & 0.072 & 0.078 & 0.072 & 0.07 \\
\hline Axis REIT & Diversified & 0.066 & 0.073 & 0.072 & 0.079 & 0.064 \\
\hline $\begin{array}{l}\text { CapitalMalls } \\
\text { Malaysia } \\
\text { Trust }\end{array}$ & Pure-Play & 0.053 & 0.07 & 0.07 & 0.063 & 0.063 \\
\hline Hektar REIT & Pure-Play & 0.067 & 0.067 & 0.048 & 0.066 & 0.062 \\
\hline IGB REIT & Pure-Play & - & - & - & 0.06 & 0.065 \\
\hline $\begin{array}{l}\text { Pavilion } \\
\text { REIT }\end{array}$ & Pure-Play & - & - & 0.055 & 0.06 & 0.05 \\
\hline $\begin{array}{l}\text { Quill Capital } \\
\text { Trust }\end{array}$ & Diversified & 0.096 & 0.097 & 0.093 & 0.093 & 0.093 \\
\hline $\begin{array}{l}\text { Sunway } \\
\text { REIT }\end{array}$ & Diversified & & 0.063 & 0.068 & 0.058 & 0.061 \\
\hline Tower REIT & Pure-Play & 0.083 & 0.09 & 0.09 & 0.087 & 0.066 \\
\hline UOA REIT & Pure-Play & 0.083 & 0.078 & 0.082 & 0.082 & 0.088 \\
\hline
\end{tabular}

Based on the property rental yield show in Table 6 , the REITs performed well in rental yield are majority pure-played property type in their property portfolio. The pure-played property types REITs focused on one particular property type and thus will provide better understanding and well management compared to those diversified property type REITs which need to employed more number of personnel to manage variety of property type in their portfolio and increased (Ro and Ziobrowski, 2011).Moreover, by holdings one particular property type is also one type of investment strategy adopted by fund manager to maximize the return and minimize the portfolio risk (Jalil and Ali, 2015; and Brown, 1991). This, seem to align with argument by Capozza \& Seguin (1999), that adversely performance of diversified property type on M-REITs. The pure-played M-REITs are performed well, since they focusing on one particular property types can avoid higher management cost and also easy to focus on particular tenant in order to fulfil their preferred and requirement on buildings. This directly can improve the return and performance of REITs (Jalil and Ali, 2015; Benefield et.al., 2009; and Chan et.al., 2003).

Overall, the study suggests that there is performance difference between property diversification strategy, in which pure-played strategy M-REITs produced higher rental yield and consequently higher distribution of dividend yield. Accordingly the unit price of M-REITs will increase, vice versa of low rental yield, produce lower dividend and affect the unit price of M-REITs diluted.

\section{Conclusion}

This study shows that property types are important determinants in determine the diversification strategy of REITs investment based on the literature. The analysis of this study shows that M- REITs' performance of dividend yield (DY) has a positive correlation value with commercial lot property type and M-REITs' performance of expected return(ER) have a highest positive correlation value with industrial property types compares to other property types. In addition, the study suggests that there is a performance difference between property diversification strategy, in which pure-played strategy M-REITs produced higher rental yield and consequently resulting in higher distribution of dividend yield in M-REITs. Besides, the analysis of this study revealed that property types have little influences to $M$ REITs performance of expected return and dividend yield. This due to M-REITs performance are influenced by others' significant factors such as location of underlying property, managing style, property type diversification and financial policy of M-REITs. Thus, it is suggested to further this study by employ these factors to examine the influence towards M-REITs performance.

\section{References}

1. Guidelines on Real Estate Investment Trust (2012). Kuala Lumpur, Malaysia. 
2. Ambrose, B. (1990). An analysis of the factors affecting light industrial property valuation. Journal of Real Estate Research, 5(3), 355-370.

3. Anderson, Randy I. , Liang Y. and Shain J.R. 2001. Deriving REIT Returns by Economic Location. Real Estate Finance.

4. Ambrose, B. W., \& Linneman, P. (2001). REIT organizational structure and operating characteristics. Journal of Real Estate Research, 21(3), 141-162.

5. Avidon, E. (1995). REITs agree: diversity= stability. National Mortgage News, 18.

6. Benefield, J. D., Anderson, R. I., \& Zumpano, L. V. (2009). Performance differences in propertytype diversified versus specialized real estate investment trusts (REITs). Review of Financial Economics, 18(2), 70-79.

7. Benjamin, J., Zietz, E., \& Sirmans, S. (2003). The environment and performance of industrial real estate. Journal of Real Estate Literature, 11(3), 279324.

8. Breidenbach, M., Mueller, G., \& Schulte, K. W. (2006). Determining real estate betas for markets and property types to set better investment hurdle rates. Journal of Real Estate Portfolio Management, 12(1), 73-80.

9. Brown, G. R. (1991). Property investment and the capital markets. Routledge.

10. Celka, K. (2011). Determinants of Office Space Choice. Journal of International Studies, 4(1), 108114.

11. Clayton, J., \& MacKinnon, G. (2003). The relative importance of stock, bond and real estate factors in explaining REIT returns. The Journal of Real Estate Finance and Economics, 27(1), 39-60.

12. Capozza, D. R., \& Korean, S. L. (1995). Property type, size and REIT value. Journal of Real Estate Research, 10(4), 363-379

13. Capozza, D. R., \& Seguin, P. J. (1999). Focus, transparency and value: the REIT evidence. Real Estate Economics, 27(4), 587-619.

14. Chen, J., \& Peiser, R. (1999). The risk and return characteristics of REITs 1993-1997. Real Estate Finance, 16, 61-68.

15. Chan, S. H., Erickson, J., \& Wang, K. (2003). Real Estate Investment Trusts: Structure: Structure, Performance, and Investment Opportunities. OUP Catalogue.

16. Danielsen, B., \& Harrison, D. (2007). The impact of property type diversification on REIT liquidity. Journal of Real Estate Portfolio Management, 13(4), 329-344.

17. Eichholtz, P. M., Hoesli, M., MacGregor, B. D., \& Nanthakumaran, N. (1995). Real estate portfolio diversification by property type and region. Journal of Property Finance, 6(3), 39-59.

18. Fehribach, F., Rutherford, R., \& Eakin, M. (1993). An analysis of the determinants of industrial property valuation. Journal of Real Estate Research, 8(3), 365-376.

19. Gyourko, J., \& Nelling, E. (1996). Systematic risk and diversification in the equity REIT market. Real Estate Economics, 24(4), 493-515.

20. Hartzell, D., Hekman, J., \& Miles, M. (1986). Diversification categories in investment real estate. Real Estate Economics, 14(2), 230-254.

21. Hui, E. C. M., Yiu, C. Y., \& Yau, Y. (2007). Retail properties in Hong Kong: a rental analysis. Journal of property investment \& finance, 25(2), 136-146.

22. Jalil, R. A., \& Ali, H. M. (2015). Performance Determinants of Malaysian Real Estate Investment Trusts. Jurnal Teknologi, 73(5).

23. Kim, H., Mattila, A. S., \& Gu, Z. (2002). Performance of hotel real estate investment trusts: a comparative analysis of Jensen indexes. International Journal of Hospitality Management, 21(1), 85-97.

24. Kim, J., \& Jang, S. (2012). Comparative analyses of hotel REITs: examining risk-return and performance characteristics. International Journal of Contemporary Hospitality Management, 24(4), 594-613.

25. LeHew, M. L., \& Fairhurst, A. E. (2000). US shopping mall attributes: an exploratory investigation of their relationship to retail productivity. International Journal of Retail \& Distribution Management, 28(6), 261-279.

26. Newell, G., Hwa, T., \& Acheampong, P. (2002). Listed property trusts in Malaysia. Journal of Real Estate Literature, 10(1), 109-118.

27. Newell, G. R. A. E. M. E., YUE, W., WING, C. K., \& KEI, W. S. (2010). The development and performance of REITs in Hong Kong. Pacific Rim Property Research Journal, 16(2), 191-206.

28. Newell, G., \& Osmadi, A. (2010). Assessing the importance of factors influencing the future development of REITs in Malaysia. Pacific Rim Property Research Journal, 16(3), 358-374.

29. Newell, G., \& Osmadi, A. (2009). The development and preliminary performance analysis of Islamic REITs in Malaysia. Journal of Property Research, 26(4), 329-347.

30. Newell, G., \& Yen Keng, T. (2003). The significance of property sector and geographic diversification in Australian institutional property portfolios. Pacific Rim Property Research Journal, 9(3), 248-264. 
31. Omisore, I., Yusuf, M., \& Christopher, N. (2011). The modern portfolio theory as an investment decision tool. Journal of Accounting and Taxation, 4(2), 19-28.

32. Olanrele, O. O., Said, R., \& Daud, M. N. (2014). Benchmark for REIT Performance in Malaysia Using Hedonic Regression Model. International Journal of Economics and Finance, 6(9), p165.

33. Olanrele, O. O., Said, R., \& Daud, M. N. (2015). Setting a Benchmark for REIT Performance in Malaysia. International Journal of Property Sciences, 5(1).

34. Pham, A. K. (2012). The dynamics of returns and volatility in the emerging and developed Asian REIT markets. Journal of Real Estate Literature, 20(1), 79-96.

35. Ro, S., \& Ziobrowski, A. J. (2011). Does focus really matter? Specialized vs. diversified REITs. The Journal of Real Estate Finance and Economics, 42(1), 68-83.

36. San, O., \& Malaysia, P. (2011). A study on the performance of Malaysian real estate investment trusts from $2005-2010$ by using net asset value approach.

37. San Ong, T., Teh, B. H., Soh, C. H., \& Yan, Y. L. (2012). Malaysian real estate investment trusts: a performance and comparative analysis. International Journal of Economics and Finance, 4(5), p73.

38. Tang, C. H. H., \& Jang, S. S. (2008). The profitability impact of REIT requirements: A comparative analysis of hotel REITS and hotel CCorporations. International Journal of Hospitality Management, 27(4), 614-622.

39. Wang, K., Erickson, J., \& Gau, G. W. (1993). Dividend policies and dividend announcement effects for real estate investment trusts. Real Estate Economics, 21(2), 185-201.

40. Wong, Y. M. (2015). Malaysia REIT: First Decade Development and Returns Characteristics. In 21st Annual Pacific-Rim Real Estate Society Conference, Kuala Lumpur, Malaysia (January 18 21, 2015).

41. Worzala, E., \& Bajtelsmit, V. (1997). Real estate asset allocation and the decisionmaking framework used by pension fund managers. Journal of Real Estate Portfolio Management, 3(1), 47-56.

42. Zietz, E., Sirmans, S., \& Friday, S. (2003). The environment and performance of real estate investment trusts. Journal of Real Estate Portfolio Management, 9(2), 127-165.

43. Hamzah, A. H., Rozali, M. B., \& Tahir, I. M. (2010). Empirical investigation on the performance of the Malaysian real estate investment trusts in pre-crisis, during crisis and post-crisis period. International Journal of Economics and Finance, 2(2), p62. 